\title{
Evaluation of Intraoperative Fluid Management
}

\section{İntraoperatif Sıv1 Yönetiminin Değerlendirilmesi}

\author{
Hakan TEMEL, Bilge KARSLI, Nurten KAYACAN, Yeşim TAŞELI, Zekiye BIGAT $\stackrel{1}{1}$ \\ 1 Akdeniz University, Faculty of Medicine, Department of Anesthesiology and Reanimation, Antalya, Turkey \\ 2 Near East University Department of Anesthesiology and Reanimation Lefkoşa, Cyprus
}

Yazışma Adresi

Correspondence Address

\section{Bilge KARSLI}

Akdeniz University, Faculty of Medicine, Department of Anesthesiology and Reanimation, Antalya, TURKEY

bilgekarsli@akdeniz.edu.tr

Geliş tarihi / Received : Şubat 08, 2021 Kabul tarihi / Accepted : Nisan 06, 2021 Elektronik yayın tarihi : Ocak 01, 2022 Online published

Bu makalede yapılacak atıf:

Cite this article as:

Temel H, Karslı B,

Kayacan N, Taşeli Y,

Bigat Z.

Evaluation of Intraoperative Fluid

Management

Akd Med J 2022; 8(1):33-41.

Hakan Temel

ORCID 0000-0003-4135-2742

Bilge Karslı

ORCID 0000-0003-4231-8300

Nurten Kayacan

ORCID 0000-0003-3542-4375

Yeşim Taşeli

ORCID 0000-0002-1742-9204

Zekiye Bigat

ORCID 0000-0002-2191-4595

\begin{abstract}
Objective:

Especially in large surgical procedures, it is recommended that the fluid treatment be performed according to the needs of the patient in the presence of hemodynamic monitoring during the operation. We aimed to review intraoperative fluid treatments and to increase awareness of intraoperative fluid management.
\end{abstract}

\section{Methods:}

The patients (393) who underwent general anesthesia were included in the study. According to the information of intraoperative fluid applications, the demographic characteristics of the patients and the amount and type of fluid that should be given according to the type of operation performed were determined.

\section{Results:}

In our study, the mean amount of fluid given to patients was found to be $2677.61 \mathrm{ml}$. The mean intraoperative fluid volume was higher in patients who were treated with IV vasopressors than in untreated patients $(3477.27 \mathrm{ml})$. When compared with patients with ASA 1-2 group, the amount of fluid given to the patients in the ASA-3 group was high $(2795 \mathrm{ml})$. Comparing the type of surgery and the amount of fluid given intraoperatively, we observed that the amount of intraoperative fluid was significantly higher in the high-risk surgical group (3601.65 ml). We can say that we are close to liberal practices as a liquid strategy. The use of balanced crystalloid with the closest content to plasma is the most preferred liquid type in our clinical practice.

\section{Conclusion:}

Due to the variability of the concepts of liberal and restrictive fluid regimen and the lack of standardized targeted clinical and physiological parameters, no specific evidence-based guideline or procedure specific fluid treatment could be demonstrated. In our study, we see that fluid replacement is performed under standard fluid treatment, which still can be considered liberal. We think that it can be useful to use hemodynamic monitoring methods more frequently in patients who need them, also in selected patient groups.

Key Words: Fluid, Liberal, Restrictive, Perioperative, Crystalloid, Colloid

\section{ÖZ}

\section{Giriş/Amaç:}

Büyük cerrahi işlemlerde, hemodinamik monitörizasyon ve hastanın ihtiyacına göre sıvı tedavisinin yapılması önerilmektedir. Biz intraoperatif sıvı tedavilerini gözden geçirmeyi ve intraoperatif sıvı ilkelerine farkındalığı arttırmayı amaçladık. 


\section{Gereç ve Yöntemler:}

Genel anestezi uygulanan hastalar (393) çalışmaya dahil edildi. İntraoperatif sıvı uygulamaları, hastaların demografik özellikleri ve yapılmış olan operasyonun türüne göre verilmesi gereken sıvı miktarları ve türü belirlendi. Hastaların mevcut kayıtlarından verilmiş olan sıvı miktarlarına ait verilerle karşılaştırılma yapılarak sonuçlar analiz edildi.

\section{Bulgular:}

Çalışmamızda hastalara verilen ortalama sıvı miktarı 2677,61 $\mathrm{ml}(11,3 \mathrm{ml} / \mathrm{kg} / \mathrm{saat})$ olarak bulunmuştur. IV vazopressör kullanılan hastalarda intraoperatif verilen ortalama s1v1 miktarlarının kullanılmayan hastalara göre daha yüksek olduğu görüldü (3477,27 ml). ASA-3 grubu hastalar ASA1-2 grubu hastalarla kıyaslandığında, ASA-3 grubu hastalara intraoperatif dönemde verilen sıvı miktarı yüksekti (2795 $\mathrm{ml}$ ). Cerrahi tipi ve intraoperatif verilen sıv1 miktarları karşılaştırıldığında; yüksek riskli cerrahi grubunda intraoperatif verilen sıv1 miktarının anlamlı olarak daha yüksek olduğunu gözlendi (3601,65 ml). Sıv1 yönetiminde liberal uygulamalara yakın değerlerde olduğumuzu söyleyebiliriz. Kristaloid kullanımı klinik pratiğimizde en sik tercih ettiğimiz sıvı tipi olarak karşımıza çıkmaktadır.

\section{Sonuç:}

Liberal ve restriktif sıvı rejimi kavramlarının değişkenliği, hedeflenen klinik ve fizyolojik parametrelerin standart olmaması nedeniyle kanıta dayalı kılavuz veya prosedüre özel bir sıvı tedavisi ortaya konamamıştır. Yüksek riskli hastalarda Sıvı yönetimi için tek tip yaklaşım uygun olmayacaktır. Bizim çalışmamızda standart sıvı tedavisi uygulamaktayız, sonuçlarımız liberal sayılabilir. Hemodinamik monitorizasyon yöntemlerine ve hastanın sıv1 gereksinimlerine dikkat edilerek replasman yapılmasının faydalı olacağını düşünmekteyiz.

Anahtar Sözcülkler: Sıv1, Liberal, Restriktif, Perioperatif, Kristalloid, Kolloid

\section{INTRODUGTION}

Fluid treatment is an integral and most important part of perioperative treatment. Maintaining intravascular volume and maintaining hemodynamic stability play an important role on postoperative morbidity and mortality. There is a well-known relationship between the volume of fluid administered to the patient in the perioperative period and postoperative morbidity. If sufficient fluid is not administered to the patient, various complications such as acute kidney damage, hypotension, heart rhythm disturbances, ischemia, anastomosis leakage may occur due to hypovolemia. If the patient is overcharged, various complications such as prolonged mechanical ventilation, delayed wound healing or infection may occur due to overloading. Therefore, keeping the fluid status of the patient in a sensitive balance in the perioperative period is critical for postoperative morbidity and mortality. In order to give sufficient fluid to the patients and to avoid the possible negative effects caused by the excess fluid, hemodynamic monitoring showing fluid response should be 34 performed and fluid treatment should be personalized for the patient by applying a rational fluid strategy (1-8).

In our study; we aimed to review the perioperative fluid applications and increase awareness of the principles of intraoperative fluid applications.

\section{METHODS}

The aim of our study was to review intraoperative fluid applications and to increase awareness on the principles of intraoperative fluid applications. we aim to evaluate the adequacy of our applications in perioperative fluid treatment in general anesthesia patients and to share our data with our clinic.

This research complies with all the relevant national regulations, institutional policies and in accordance with the tenets of the Helsinki Declaration, and has been approved by the Akdeniz University Medical Faculty Ethical Committee (approval number: 24.02.2016/148).

In this prospective-observational study, patients aged 18-65 years who underwent elective surgery with general anesthesia were included in the study. Pediatric and geriatric patients undergoing regional anesthesia were excluded from the study.

There are no termination criteria for our study because the observational evaluation is qualified and it will be performed in patients undergoing general anesthesia without changing the general anesthesia practices. Intraoperative drugs, blood and fluid infusions and blood-fluid losses are recorded in anesthesia follow-up forms in all patients who underwent anesthesia for surgical intervention. Our study was based on the records in these forms. After the operation was completed, the information in the Anesthesia Follow-up Form of the patients was recorded in our study form. There was no intervention or contribution to anesthesia method, drug, liquid-blood infusions.

When calculating the amount of fluid that patients should take during the intraoperative period:

1. Preoperative fluid deficits were calculated according to preoperative fasting periods and patient characteristics.

2. The amount of intravenous fluid to be given according to the duration of operation in the intraoperative period was calculated.

3. Fluid loss was calculated according to the type of operation (light-medium-heavy) and additional fluid needs were determined.

With the data obtained from these calculations, the total intraoperative need of the patients was determined and compared with the total amount of fluid given during the operation.

The patients included in the study were divided into 3 classes according to the size of the surgical intervention. This is due to the increased capillary permeability due to a number of mediators released during the surgery in response to surgical trauma, depending on the size of the surgical procedure, a certain amount of fluid escapes the vessel, ie the interstitial space and the third cavities (intestinal lumen, peritoneal cavity, pleural space, etc.). This leakage can be up to 6 $\mathrm{ml} / \mathrm{kg} / \mathrm{h}$ in a low-grade surgery, up to $8 \mathrm{ml} / \mathrm{kg} / \mathrm{h}$ in a medi- 
um-grade surgery and up to $10-20 \mathrm{ml} / \mathrm{kg} / \mathrm{h}$ in a high-grade surgery.

In our study, the parameters that we evaluated during the anesthesia, including the fluids we administered during the intraoperative period and blood-fluid losses due to surgery are listed below:

- Demographic characteristics of patients

- Duration and type of operation

- Intraoperative hemodynamic monitoring

(blood pressure, heart rate)

- Is there a preoperative fluid infusion?

- Intraoperative IV fluid treatment and amount

- Losses from perioperative catheters (urine, nasogastric)

- Perioperative blood-fluid (acid fluid) losses

- Additional systemic diseases of patients

- Intravenous vascular access

- Intraoperative vasopressor use

\section{Statistical Evaluation}

Descriptive findings are presented in percentages when data are counted. In the case of data specified by measurement; the data are presented in averages and standard deviations if normal distribution is present, and in median and quartiles and min-max values if no normal distribution is present. Chi-square test was used to compare two or more groups in the census data.

In the case of continuous measurement, comparison of two independent groups; Student $t$ test (significance test of difference between two means in independent groups) if it is suitable for normal distribution, and Mann Whitney-u test which is non-parametric equivalent if it is not suitable for normal distribution. The mean of three or more groups were compared with Analysis of Variances (ANOVA) and scheffe was used as post hoc test.

\section{RESULTS}

A total of 393 patients aged 18-65 years who underwent elective surgery with general anesthesia were included in the study. Demographic characteristics of the patients included in the study are shown in Table I and Figure 1.

Table I. Characteristics of the patients in the study

\begin{tabular}{|l|c|c|c|}
\hline \multicolumn{2}{|c|}{} & $\begin{array}{c}\text { Mean } \pm \text { SD } \\
(\mathrm{n})\end{array}$ & $\begin{array}{c}\text { Min-Max } \\
(\%)\end{array}$ \\
\hline \multirow{2}{*}{ Age } & Mean \pm SD & $46.95 \pm 13.87$ & $18-65$ \\
\hline \multirow{3}{*}{ Gender } & Female & 252 & $\% 64.1$ \\
\cline { 2 - 4 } & Male & 141 & $\% 35.9$ \\
\hline \multirow{3}{*}{ ASA } & 1 & 196 & $\% 49.9$ \\
\cline { 2 - 4 } & 2 & 147 & $\% 37.4$ \\
\cline { 2 - 4 } & 3 & 50 & $\% 12.7$ \\
\hline \multirow{2}{*}{ Weight } & Mean \pm SD & $73.99 \pm 13.49 \mathrm{~kg}$ & $40-130 \mathrm{~kg}$ \\
\hline
\end{tabular}

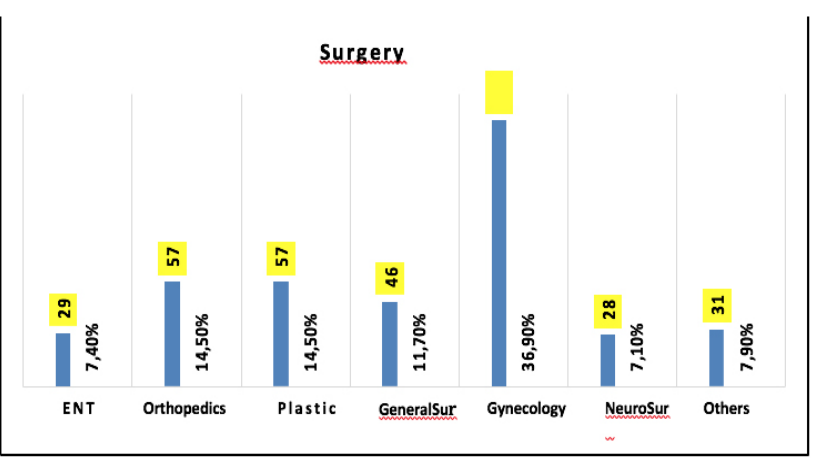

Figure1. Distribution of patients according to surgery

Patients were divided into three groups according to intraoperative fluid infusion.

$6 \mathrm{ml} / \mathrm{kg} / \mathrm{h}$ group (small surgical group), $8 \mathrm{ml} / \mathrm{kg} / \mathrm{h}$ group (middle surgical group) and $10 \mathrm{ml} / \mathrm{kg} / \mathrm{h}$ group (large surgical group) were identified (Table II).

Table II. Surgical intervention and operation time

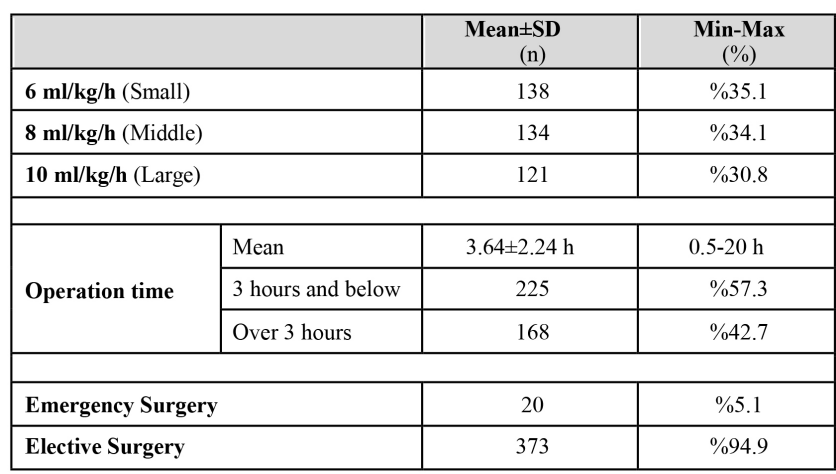

The mean preoperative fasting time of the patients was 10.73 \pm 2.66 hours. There were 287 patients with a fasting period of 9 hours or more. This is $73 \%$ of patients. The number of patients receiving IV fluid infusion in the preoperative period was 73 patients, this is $18.6 \%$ of patients. The fluid infusion in patients is summarized in Table III.

Table III. Fluids given to patients and fasting periods

\begin{tabular}{|c|c|c|c|}
\hline & & Number (n) & Percent (\%) \\
\hline Preoperative IV Flu & d Infusion-YES & 73 & $\% 18.6$ \\
\hline Preoperative IV Flu & d Infusion-NO & 320 & $\% 81.4$ \\
\hline & Isolyte-S & 291 & $\% 74.0$ \\
\hline Intraoperative Fluid & Serum Physiological & 139 & $\% 35.4$ \\
\hline & Colloid & 116 & $\% 29.5$ \\
\hline & Ringer Lactat & 3 & $\% 0.7$ \\
\hline Preoperative Mean F & asting Time & 10.73 & \\
\hline Fasting time 9 hours & and over & 287 & $\% 73.0$ \\
\hline Blood Replacement & & 58 & $\% 14.8$ \\
\hline Plasma Replacement & & 33 & $\% 8.4$ \\
\hline Platelet Replacement & & 1 & $\% 0.2$ \\
\hline Acid fluid drained & & 13 & $\% 3.3$ \\
\hline
\end{tabular}


When the patients who participated in the study were compared in terms of the size of the surgical intervention and the amount of fluid given, it was found that the amount of fluid increased significantly as the size of the surgical intervention increased $(\mathrm{p}<0.05)$ (Table IV).

Table IV. Surgery and intraoperative fluid volumes

\begin{tabular}{|c|c|c|c|}
\hline & & $\begin{array}{l}\text { Intraoperative fluid } \\
\text { volumes (Mean) }\end{array}$ & $\mathbf{P}^{*}$ \\
\hline \multirow{3}{*}{ Surgery } & 6 ml/kg/h (Small) & $1625.36 \pm 703.72 \mathrm{ml}$ & \multirow{3}{*}{$P<0.05$} \\
\hline & 8 ml/kg/h (Middle) & $2926.87 \pm 1251.17 \mathrm{ml}$ & \\
\hline & $10 \mathrm{ml} / \mathrm{kg} / \mathrm{h}$ (Large) & $3601.65 \pm 1949.70 \mathrm{ml}$ & \\
\hline
\end{tabular}

There was no significant difference between the amount of IV fluid given between the surgical branches examined in the study $(\mathrm{p}>0.05)($ Table V).

Table V. Surgery and intraoperative fluid volumes

\begin{tabular}{|c|c|c|c|c|}
\hline & \multicolumn{2}{|c|}{ Amount of fluid delivered } & \multirow[b]{2}{*}{$\mathbf{P}^{*}$} \\
\hline & & $\begin{array}{c}\text { Number } \\
\text { (n) }\end{array}$ & Mean \pm SD & \\
\hline \multirow{7}{*}{ Surgery } & ENT & 29 & $2068.97 \pm 1874.28 \mathrm{ml}$ & \multirow{8}{*}{$\mathrm{P}>0.05$} \\
\hline & Orthopedics & 57 & $2921.05 \pm 1638.78 \mathrm{ml}$ & \\
\hline & Plastic surgery & 57 & $2552.63 \pm 2342.70 \mathrm{ml}$ & \\
\hline & Chest surgery & 46 & $2423.91 \pm 1476.54 \mathrm{ml}$ & \\
\hline & Gynecology & 145 & $2795.86 \pm 1163.20 \mathrm{ml}$ & \\
\hline & Neurosurgery & 28 & $2782.14 \pm 1124.82 \mathrm{ml}$ & \\
\hline & Others & 31 & $2758.06 \pm 1760.07 \mathrm{ml}$ & \\
\hline & Total & 393 & $2677.61 \pm 1594.51 \mathrm{ml}$ & \\
\hline
\end{tabular}

When the patients receiving IV vasopressor were examined in terms of their relationship with the mean amount of fluid administered intraoperatively, it was observed that patients receiving IV vasopressor had significantly higher fluid intake during the intraoperative period ( $\mathrm{p}<0.05)$. In the comparison of the mean amount of fluid administered in the intraoperative period with the ASA groups, no significant relationship was found. In addition, when the groups of patients undergoing emergency and elective surgery were evaluated in terms of the mean amount of fluid delivered during the intraoperative period, it was seen that the mean amount of fluid given intraoperatively was higher in emergency operations. However, this relationship was not statistically significant $(\mathrm{p}>$ 0.05 ). There was no significant difference between the mean fluid intake of the patients according to surgical types during the intraoperative period. When intraoperative mean blood flow and fresh frozen plasma were examined in terms of intraoperative mean fluid volume, it was found that the amount of fluid given in patients who underwent blood and plasma replacement was significantly higher $(\mathrm{p}<0.05)$ (Table VI).
Table VI. Comparison of intraoperative fluid intake in different groups

\begin{tabular}{|c|c|c|c|}
\hline & & $\begin{array}{c}\text { Intraoperative fluid } \\
\text { (Mean) }\end{array}$ & $\mathbf{P}^{*}$ \\
\hline \multirow{2}{*}{$\begin{array}{l}\text { IV Vasopressor } \\
\text { drug }\end{array}$} & $\mathbf{0}$ & $2604.31 \pm 1516.45 \mathrm{ml}$ & \multirow{2}{*}{$P<0.05$} \\
\hline & 1 & $3477.27 \pm 2150.91 \mathrm{ml}$ & \\
\hline \multirow{2}{*}{ ASA } & I-II & $2660.50 \pm 1618.53 \mathrm{ml}$ & \multirow{2}{*}{$\mathrm{P}>0.05$} \\
\hline & 3 & $2795.00 \pm 1428.15 \mathrm{ml}$ & \\
\hline \multicolumn{2}{|l|}{ Elective Surgery } & $2654.96 \pm 1558.09 \mathrm{ml}$ & \multirow{2}{*}{$\mathrm{P}>0.05$} \\
\hline \multicolumn{2}{|c|}{ Emergency Surgery } & $3100.00 \pm 2174.00 \mathrm{ml}$ & \\
\hline \multirow{2}{*}{ Blood } & $\mathbf{0}$ & $2396.42 \pm 1300.27 \mathrm{ml}$ & \multirow{2}{*}{$P<0.05$} \\
\hline & 1 & $4301.72 \pm 2104.58 \mathrm{ml}$ & \\
\hline \multirow{2}{*}{ Plasma } & $\mathbf{0}$ & $2543.89 \pm 1532.24 \mathrm{ml}$ & \multirow{2}{*}{$P<0.05$} \\
\hline & 1 & $4136.36 \pm 1552.58 \mathrm{ml}$ & \\
\hline \multicolumn{2}{|l|}{ Mean fluid volume } & $2677.61 \pm 1594.51 \mathrm{ml}$ & $\begin{array}{l}11.31 \pm 5.66 \\
\mathrm{ml} / \mathrm{kg} / \mathrm{h}\end{array}$ \\
\hline
\end{tabular}

According to these results, preoperative IV fluid replacement is performed only in $18.6 \%$ of the patients (Table VII).

Table VII. Preoperative IV fluid infusion rates according to the surgery

\begin{tabular}{|c|c|c|c|c|}
\hline & \multicolumn{2}{|c|}{ Preop IV Fluid Infusion } & \multirow{2}{*}{ Total } \\
\hline & & NO & YES & \\
\hline \multirow{7}{*}{ Surgery } & ENT & $26(\% 89.7)$ & $3(\% 10.3)$ & $29(\% 100)$ \\
\hline & Orthopedics & $43(\% 75.4)$ & $14(\% 24.6)$ & $57(\% 100)$ \\
\hline & Plastic surgery & $54(\% 94.7)$ & $3(\% 5.3)$ & $57(\% 100)$ \\
\hline & Chest surgery & $34(\% 73.9)$ & $12(\% 26.1)$ & $46(\% 100)$ \\
\hline & Gynecology & $118(\% 81.4)$ & $27(\% 18.6)$ & $145(\% 100)$ \\
\hline & Neurosurgery & $20(\% 71.4)$ & $8(\% 28.6)$ & $28(\% 100)$ \\
\hline & Others & $25(\% 80.6)$ & $6(\% 19.4)$ & $31(\% 100)$ \\
\hline \multicolumn{2}{|r|}{ Total } & $320(\% 81.4)$ & 73 (\%18.6) & $393(\% 100)$ \\
\hline
\end{tabular}

The amount of fluid to be given to the patients participating in the study was calculated based on the 4-2-1 rule. Considering this calculation, the differences between the amount of fluid given to the patients and the amount of fluid to be given were examined. Of the 393 patients who participated in the study, 28 of them had the amount of fluid given; the amount of fluid that the patient should take. Of these 28 patients were orthopedic patients who had undergone extremity surgery for more than 3 hours, and 23 of them were general surgery, urology and gynecology cases who had abdominal surgery.

The amount of fluid delivered to the patient was greater than the amount of fluid required in 28 patients. In the other 365 patients, the amount of fluid given to the patient was equal to or less than the amount of fluid that the patient had to take. In the evaluation of this last group of patients, some analyzes were performed by measuring the amount of missing fluid. In these analyzes, missing fluid measurements of 28 patients in the first group were considered to be zero in order not to affect the evaluation.

Of the 393 patients who participated in the study, the amount of fluid given to the patients was lower than the amount of fluid required in 365 patients. The comparison of the amount of fluid given to patients with different parameters is shown 
in Table VIII.

Table VIII. Examination of the amount of incomplete fluid given intraoperatively in different groups

\begin{tabular}{|c|c|c|c|}
\hline & & $\begin{array}{l}\text { Incomplete fluid given } \\
\text { intraoperatively (mean) }\end{array}$ & $\mathbf{P}^{*}$ \\
\hline \multirow{2}{*}{$\begin{array}{l}\text { IV Vasopressor } \\
\text { drug }\end{array}$} & NO & $1216.48 \pm 1240.83 \mathrm{ml}$ & \multirow{2}{*}{$\mathrm{P}>0.05$} \\
\hline & YES & $1391.97 \pm 1587.83 \mathrm{ml}$ & \\
\hline \multirow{2}{*}{ ASA } & I-II & $1196.44 \pm 1267.47 \mathrm{ml}$ & \multirow{2}{*}{$\mathrm{P}>0.05$} \\
\hline & III & $1469.80 \pm 1290.61 \mathrm{ml}$ & \\
\hline \multicolumn{2}{|l|}{ Elective Surgery } & $1258.38 \pm 1285.05 \mathrm{ml}$ & \multirow{2}{*}{$\mathrm{P}>0.05$} \\
\hline \multicolumn{2}{|l|}{ Emergency Surgery } & $724.60 \pm 876.11 \mathrm{ml}$ & \\
\hline \multirow{2}{*}{ Blood } & NO & $1198.22 \pm 1240.80 \mathrm{ml}$ & \multirow{2}{*}{$\mathrm{P}>0.05$} \\
\hline & YES & $1421.81 \pm 1436.35 \mathrm{ml}$ & \\
\hline \multirow{2}{*}{ Operation Time } & 3 hours and below & $767.03 \pm 765.93 \mathrm{ml}$ & \multirow{2}{*}{$P<0.05$} \\
\hline & Over 3 hours & $1852.91 \pm 1527.14 \mathrm{ml}$ & \\
\hline \multicolumn{2}{|c|}{ Mean volume of fluid given to patients } & $2677.61 \pm 1594.51 \mathrm{ml}$ & $\begin{array}{l}11.31 \pm 5.66 \\
\mathrm{ml} / \mathrm{kg} / \mathrm{h}\end{array}$ \\
\hline
\end{tabular}

We observed that patients with ASA III were given less liquid than ASA I-II patients, but this difference was not statistically significant. In the elective surgery group, the amount of deficient fluid given was less than the emergency operation group. However, this difference was not statistically significant. When the amount of fluid given was analyzed in terms of operation time, it was seen that less fluid was given in the group with operation time of 3 hours or more compared to the group with operation time less than 3 hours $(p<0.05)$.

The comparison of the amount of missing fluid given to the patients who participated in the study with the type of surgery (size of the surgical intervention) is given in Table IX.

Table IX. Surgery and incomplete fluid given intraoperatively

\begin{tabular}{|l|l|c|c|}
\hline \multicolumn{2}{|c|}{} & Incomplete fluid (mean) & \multirow{2}{*}{$\mathrm{P}^{*}$} \\
\hline \multirow{3}{*}{ Surgery } & $\mathbf{6 ~ m l} / \mathbf{k g} / \mathbf{h}$ (Small) & $1117.33 \pm 1200.00 \mathrm{ml}$ & \multirow{3}{*}{$\boldsymbol{P}<0.05^{* *}$} \\
\cline { 2 - 3 } & $\mathbf{8 ~ m l} / \mathbf{k g} / \mathbf{h}$ (Middle) & $784.76 \pm 787.24 \mathrm{ml}$ & \\
\cline { 2 - 3 } & $\mathbf{1 0 ~} \mathrm{ml} / \mathbf{k g} / \mathbf{h}$ (Large) & $1855.53 \pm 1524.60 \mathrm{ml}$ & \\
\hline $\begin{array}{l}\text { * Analysis of variance was performed } \\
\text { ** Comparison of 10 ml/kg/h group with two other groups }\end{array}$ \\
\hline
\end{tabular}

As a result of the variance analysis, it was found that an average of $1855.53 \mathrm{ml}$ of incomplete fluid replacement was performed in the $10 \mathrm{ml} / \mathrm{kg} / \mathrm{h}$ (high-risk surgeries) group. In the $10 \mathrm{ml} / \mathrm{kg} / \mathrm{h}$ group, the amount of deficient fluid was significantly higher than the $6 \mathrm{ml} / \mathrm{kg} / \mathrm{h}$ and $8 \mathrm{ml} / \mathrm{kg} / \mathrm{h}$ groups $(\mathrm{p}<0.05)$. No significant difference was found between the 6 $\mathrm{ml} / \mathrm{kg} / \mathrm{h}$ and $8 \mathrm{ml} / \mathrm{kg} / \mathrm{h}$ groups.

The comparison of the amount of fluid given to the patients according to the branches is shown in Table X. While the missing amount was the highest in the ENT group (mean $2504.31 \mathrm{ml})$, it was observed that the missing amount (729.94 $\mathrm{ml}$ ) in the Gynecology group was the lowest compared to other branches.

Table X. Surgery and incomplete fluid given intraoperatively

\begin{tabular}{|l|l|c|c|}
\hline \multicolumn{2}{|c|}{} & \multicolumn{2}{c|}{ Incomplete fluid given intraoperatively } \\
\cline { 3 - 4 } \multicolumn{2}{|c|}{} & Number(n) & Mean \pm SD \\
\hline \multirow{5}{*}{ Surgery } & ENT & 29 & $2504.31 \pm 1832.42 \mathrm{ml}$ \\
\cline { 2 - 4 } & Orthopedics & 57 & $1153.28 \pm 1077.36 \mathrm{ml}$ \\
\cline { 2 - 4 } & Plastic surgery & 57 & $1466.66 \pm 1450.92 \mathrm{ml}$ \\
\cline { 2 - 4 } & Chest surgery & 46 & $1392.87 \pm 1327.83 \mathrm{ml}$ \\
\cline { 2 - 4 } & Gynecology & 145 & $729.94 \pm 868.59 \mathrm{ml}$ \\
\cline { 2 - 4 } & Neurosurgery & 28 & $1714.82 \pm 1077.45 \mathrm{ml}$ \\
\cline { 2 - 4 } & Others & 31 & $1418.71 \pm 1187.10 \mathrm{ml}$ \\
\hline \multirow{4}{*}{ Total } & & 393 & $1231.22 \pm 1272.04 \mathrm{ml}$ \\
\hline
\end{tabular}

\section{DISGUSSION}

The perioperative fluid therapy is a highly controversial issue, data from these studies suggest that targeted fluid therapy may reduce postoperative major complications in order to achieve hemodynamic stability. The lack of standard criteria for perioperative fluid treatment leads to very different clinical applications. There are discussions about intraoperative fluid management with variable recommendations for fluid composition and volume applied.

The hemodynamic monitoring that predicts fluid response should be performed and fluid treatment should be personalized for the patient in order to give patients the optimum fluid and avoid any possible adverse effects caused by excess fluid. It is an effective method for maintaining hemodynamic stability and providing adequate intravascular volume. Hypovolemia as well as excessive fluid overload can have serious negative consequences $(9,10)$.

It is still unclear which criteria will be used in the selection of fluid therapy. The reason for the lack of a fixed approach is that the scientific principles on which liquid application is based are constantly changing as a result of current studies (11).

There are many studies on fluid treatment that should be applied during the operation. Particular emphasis is given to standard, restrictive and individualized targeted fluid treatment methods. However, there is no widely accepted definition for these free and restrictive fluid treatment methods. In studies comparing free and restrictive fluid therapies, differences in pre- and postoperative patient data, complexity, amount and type of fluids used, additional fluid or inotropic requirement during surgery, and non-standardization of the surgical team complicate the interpretation of these results. Excessive fluid administration in standard fluid treatment may result in an increase in venous pressure and fluid passage into the intracellular areas, resulting in pulmonary and peripheral edema and consequently reduced systemic and local tissue oxygenation. The use of crystalloids especially in the treatment of free fluid may cause problems such as weight gain, bowel edema, dilution of coagulation factors, anastomotic leaks, longer hospital stay, and increased costs. In addition, free fluid treatment in outpatient surgical patients has been shown to reduce postoperative pain, dizziness, nausea and vomiting $(8,12)$.

Restrictive fluid therapy aims to provide the least amount of fluid without leaving patients hypovolemic. The aim is to 
keep the amount of fluid that the patient receives and removes as much as possible and to avoid weight gain due to fluid therapy. Studies have shown that the complications that may occur after surgical intervention are reduced with restrictive fluid therapy. However, there are reports showing that a hypovolemia that may have consequences such as risk of cardiac output reduction and multiple organ failure may occur (12-14).

In our study, we aimed to review the perioperative fluid applications and increase awareness of the principles of intraoperative fluid applications.

In a total of 152 patients undergoing elective intraabdominal surgery performed by Nisanevich $\mathrm{V}$ et al., liberal fluid treatment $(10 \mathrm{ml} / \mathrm{kg}$ bolus after $12 \mathrm{ml} / \mathrm{kg} / \mathrm{h}$ infusion) and restrictive fluid treatment $(4 \mathrm{ml} / \mathrm{kg} / \mathrm{h})$ were compared. As a result, it was found that the length of hospital stay in the restrictive group was significantly shorter and postoperative weight gain was less in the restrictive group, and there was no significant difference in terms of other complications (12).

In our study, ASA (I-II-III) patient groups were compared by calculating the amount of fluid they received and the standard amount of fluid (fasting, maintenance, surgical fluid requirement according to the 4-2-1 rule). Based on the standard fluid requirement (liberal approach), it was found that the amount of fluid received by the patients was low and the total amount of fluid left behind.

In a prospective study of 61 patients who underwent abdominal surgery by Aguilar-Nascimento JE et al., they compared mean postoperative morbidity and length of hospital stay by giving $2100 \mathrm{ml}$ of fluid to the restrictive fluid group and 3575 $\mathrm{ml}$ to the free fluid group. In the study, it has been reported that restrictive fluid treatment reduces morbidity and time of hospital stay (13). In another randomized controlled study by Holte K et al., 48 patients with knee replacement surgery were included in the study. $4250 \mathrm{ml}$ fluid was applied to the standard fluid treatment group and $1740 \mathrm{ml}$ fluid was applied to the limited fluid treatment group, respectively. At the end of the study, it was found that free fluid therapy reduces postoperative vomiting and hypercoagulability compared to restrictive fluid therapy (15).

In our study, the mean amount of fluid given to patients was $2677 \mathrm{ml}(11.3 \mathrm{ml} / \mathrm{kg} / \mathrm{h})$. The amount of fluid given is between the restrictive and standard groups in this study. In our study, no investigation was made in terms of morbidity and length of hospitalization. In our study, no examination was made in terms of postoperative complications.

In a randomized controlled study by Noblett et al., 108 patients undergoing colorectal surgery were examined. Patients were divided into targeted fluid therapy $(3638 \mathrm{ml})$ and standard fluid therapy (3854 ml) groups. IL-6 levels were significantly lower in the targeted fluid treatment group. In a study on rats conducted by Klemannet al, it was observed that over-crystalloid loading induced an increase in both systemic inlammatory response markers and degradation of collagen. In the results of this study, the hypothesis that the inflammatory process would delay wound healing was emphasized. It has been reported that vasopressor therapy can be started early in order to prevent fluid overloading $(16,17)$.
In our study, the mean amount of fluid given intraoperatively was found to be statistically higher in patients receiving IV vasopressor. As a result, it was thought that patients who underwent IV vasopressor may be present in high-risk surgery and high-risk patients and therefore may be at risk of developing more complications in the operation. Another finding that supports this is the high amount of fluid given to ASA III patients in the ASA III group when compared to ASA II patients. This suggests that vasopressor agents and fluid infusion are used together to achieve hemodynamic stability. In a study conducted by Jacob et al., in healthy adults undergoing elective surgery, it has been shown that preoperative long periods of fasting have negative effects on patients' cardiopulmonary function and provoke hypovolemia (18). In our study, preoperative fasting periods were significantly longer (mean fasting time:10.7 hours) when different surgical branches were examined. Fasting patients for 9 hours or more make up $73 \%$ of all patients.

In our study, when the data related to the use of colloid in our clinic were examined; In $29.5 \%$ of patients, colloid was used. No case of colloid fluid replacement over $1000 \mathrm{ml}$ was observed.

In a study by Perel et al., dilutional anemia may be considered as an important cause of shock (5th shock type) that disrupts nutrition at the cell level. It was stated that excessive fluid application would cause an increase in blood transfusion amount due to dilutional anemia and hemoglobin value would be decreased by approximately $1.1 \mathrm{~g} / \mathrm{dl}$ after replacement of $500 \mathrm{ml}$ fluid (19).

In our study; Intraoperative fluid administration was found to be higher in patients who underwent blood and plasma replacement during intraoperative period. This may be due to dilutional anemia or lack of intravascular volume lost by surgical bleeding.

In studies examining the effects of fluids on plasma, it has been observed that balanced replacement solutions least disrupt the electrolyte balance and positively affect the plasma $\mathrm{pH}$ value.

Hyperchloremic acidosis due to the physiological applications of serum manifests itself as a common problem $(20,21)$. In our study, when the fluid types given in the intraoperative period are examined, we see that the most preferred crystalloid type is balanced crystalloid solution (isolyte-S) in 74\%. The use of balanced crystalloid which has the closest plasma content is the most commonly preferred type of fluid in our clinical practice.

While fluid restriction is the standard practice in thoracic surgery, intraoperative fluid volume varies in the general surgery. In the study of 141 cases in colorectal surgery, the liberal and (2.7 L, largely colloid) restrictive (5.4 L, largely saline) fluid regimen were compared (22). In our study, postoperative complications were $51 \%$ in the liberal group, but significantly decreased in the restrictive group and were $33 \%$. There was no increase in renal complications in restrictive group. In an article evaluating the effects of restrictive and liberal fluid regimens on postoperative outcome, it was emphasized that there is no clear definition for these two application protocols in clinical practice. It has been observed 
that standard, restrictive and liberal fluid applications do not apply high amounts of liquid which will cause damage. There were no significant differences in the patients with postoperative complications (21-24).

Corcoran $\mathrm{T}$ and colleagues reported that targeted fluid treatment applications were significantly better than liberal fluid treatment (25).

According to other fluid treatment methods, individualized targeted fluid treatment and zero balance fluid treatment applications are more effective in achieving hemodynamic balance, increasing tissue perfusion and reducing surgical complications; It is reported to provide a reduction in hospital stay and maintenance costs (26).

They reported that "zero-balance fluid therapy" (which can be considered as one of the restrictive fluid strategies) is sufficient in the intraoperative period and that one of the most recent approaches, targeted fluid therapy, should be applied in all patients (27).

In our study, we concluded that the amount of fluid given to the patients during intraoperative fluid treatment was mostly missing from the amount of fluid that patients should take. We found that the amount of fluid given was not statistically significant, but was higher in ASA III group than in ASA I-II group. We concluded that the amount of fluid given was significantly higher in the $10 \mathrm{ml} / \mathrm{kg} / \mathrm{h}$ large surgical group. We also observed that in cases of prolonged surgery, we gave statistically significantly more incomplete fluid. In conclusion, in parallel with current approaches in our anesthesia clinic, we can conclude that in high-risk surgeries and high-risk patient groups, we pay more attention to avoiding liberal fluid applications with incomplete fluid applications in intraoperative period compared to other patient groups. However, since the calculation of the amount of fluid required by our patients is determined by a calculation considered as liberal fluid treatment, we should emphasize that the amount of the missing fluid may not be within the range that can be considered as restrictive fluid application.

In our study, we determined that the amount of deficient fluid given to patients undergoing ENT surgery was higher than the other groups. In our anesthesia clinic, we think that especially controlled hypotension applications that we perform in ENT operations are effective in this result. When the deficient fluids according to the operation time was analyzed, we found that the amount of intravenous deficient fluid was significantly higher in the group of patients with an operation time over 3 hours. In conclusion, we think that preoperative fluid deficits in the first three hours of operation may have an effect on the calculation of the amount of fluid that patients should receive.
Evaluation of Intraoperative Fluid Management

\section{CONGLUSION}

In our study, due to the variability of the liberal and restrictive fluid regimen concepts and the non-standard clinical and physiological parameters targeted, no evidence-based guideline or procedure-specific fluid treatment could be established. Uniform approach for fluid management in high-risk patients will not be appropriate.

Especially in large surgical interventions, it is recommended that fluid treatment be performed during surgery with hemodynamic monitoring and according to the patient's needs. Adequate equipment and the presence of an anesthesiologist with sufficient clinical experience is an important factor that will increase the individualized targeted fluid treatment. In our study, we observed that fluid replacement was performed under the calculation we performed according to standard fluid treatment, but for our results, which are still at a liberal level, it would be beneficial to consider hemodynamic monitoring methods more frequently in patients in need, especially considering the fluid requirements of the patient in selected groups. There is a wide range of studies that can be used more safely for the individualized targeted fluid treatment approach in large surgical interventions and high-risk patient groups. Therefore, there is a need for new scientific studies on fluid treatment during the surgical procedure. In this way, by making the standard definition of liquid applications, the effects and results of these applications will be better understood.

Ethics Committee Approval: This research complies with all the relevant national regulations, institutional policies and is in accordance with the tenets of the Helsinki Declaration, and has been approved by the Akdeniz University Medical Faculty Ethical Committee, (approval number: 24.02.2016/148).

Informed Consent: All the participants' rights were protected and written informed consents were obtained before the procedures according to the Helsinki Declaration.

Author Contributions: Concept - H.T., B.K.; Design - H.T., B.K.,NK; Supervision - H.T., B.K.,NK.; Resources - H.T., B.K., NK.; Materials - H.T., B.K.,Y.T.; Data Collection and/or Processing - H.T., B.K.; Analysis and/ or Interpretation - H.T., B.K.; Literature Search - H.T., B.K.; Writing Manuscript - H.T., B.K.N.K.,Y.Ç.,Z.B.; Critical Review H.T., B.K.N.K.,Y.Ç.,Z.B.

Conflict of Interest: The authors have no conflict of interest to declare.

Financial Disclosure: The authors declared that this study has received no financial support. 
Karslı B. et al

\section{REFERENGES}

1. Yeager MP, Spence BC. Perioperative Fluid Management: Current consensus and controversies. Semin Dial 2006; 19: 472-9.

2. Kaye AD, Riopelle JM. Intravasculer Fluid and Electrolyte Physiology. In: Miller RD. Miller's Anesthesia (7th ed). Elsevier Churchill Livingstone: Philadelphia 2010; 1728-30.

3. Holte K, Sharrock NE, Kehlet H. Pathophysiology and clinical implications of perioperative fluid excess. Br J Anaesth 2002; 89: 622-32.

4. Chappel D, Jacob M, Hofmann-Kiefer K, Conzen P, Rehm M. A Rational Approach to Perioperative Fluid Management. Anesthesiology 2008; 109: 723-40.

5. Nisanevich V, Felsenstein I, Almogy G, Weissman C, Einav S, Matot I. Effect of intraoperative fluid management on outcome after intraabdominal surgery. Anesthesiology 2005; 103: 25-32.

6. Arkilic CF, Taguchi A, Sharma N, Ratnaraj J, Sessler DI, Read TE, Fleshman JW, Kurz A. Supplemental perioperative fluid administration increases tissue oxygen pressure. Surgery 2003; 133(1): 49-55.

7. Kimberger O, Fleischmann E, Brandt S, Kugener A, Kabon B, Hiltebrand L, Krejci V, Kurz A. Supplemental oxygen, but not supplemental crystalloid fluid, increases tissue oxygen tension in healthy and anastomotic colon in pigs. Anesth Analg 2007; 105(3):773-9.

8. Doherty M, Buggy D. Intraoperative fluids: how much is too much? J British Journal of Anaesthesia 2012; 109(1): 69-79.

9. Gupta R, Gan TJ. Peri-operative fluid management to enhance recovery. Anaesthesia 2016; 71 Suppl 1: 40-5.

10. Della Rocca G, Vetrugno L. Fluid therapy today: Where are we? Turk J Anaesth Reanim 2016; 44(5): 233-5.

11. Rocca GD, Vetrugno L, Tripi G, Deana C, Barbariol F, Pompei L. Liberal or restricted fluid administration: are we ready for a proposal of a restricted intraoperative approach? Bio Medical Central Anesthesiology 2014; 14: 62 .

12. Nisanveich V, Feisenstein J, Almogy G, Weissman C, Einav S, Matot I. Effect of intraoperative fluid management on outcome after intraabdominal surgery. Anesthesiology 2005; 103: 25-32.

13. De Aguilar-Nascimento JE, Diniz BN, do Carmo AV, Silveira EAO, Silva RM. Clinical benefits after the implementation of a protocol of restricted perioperative intravenous crystalloid fluids in major abdominal operations. World Journal of Surgery 2009; 33(5): 925-30.

14. Warrillow SJ, Weinberg L, Parker F, Calzavacca P, Licari E. Perioperative fluid prescription, complications, and outcomes in major elective open gastrointestinal surgery. Anaesth Intensive Care 2010; 38: 251-65.

15. Holte K, Kristensen BB, Valentiner L, Kehlet H. Liberal Versus Restrictive Fluid Management in Knee Arthroplasty: A Randomized, Double-Blind Study. Anesthesia and Analgesia 2007; 105(2): 465-74.

16. Noblett SE, Snowden CP, Shenton BK, Horgan AF. Randomized clinical trial assessing the effect of Doppler-optimized fluid management on outcome after elective colorectal resection. Br J Surg 2006; 93(9): 1069-76.

17. Kulemann B, Timme S, Seifert G,Holzner PA, Glatz T, Sick O, Chikhladze S, Bronsert B, Hoepner J, Werner M, Hopt VT, Marjanovic G. Intraoperative crystalloid overload leads to substantial inflammatory infiltration of intestinal anastomoses - a histomorphological analysis. Surgery 2013; 154(3): 596-603.

18. Jacob M, Chappell D, Conzen P, Finsterer U, Rehm M. Blood volume is normal after pre-operative overnight fasting. Acta Anaesthesiol Scand 2008; 52: 522-9.

19. Perel A. Iatrogenic hemodilution: a possible cause for avoidable blood transfusions? Critical Care 2017; 21(1): 291.

20. Semler MW. Self WH, Wanderer JP, Ehrenfeld JM, Wang L, Bryn DW, Stollings JL, Kumar AB, Hughes CG, Hernandez A, Guillamondegui OD, May AK, Weavind L, Casey JD, Siew ED, Shaw AD, Rice TW. Balanced Crystalloids versus Saline in Critically Ill Adults. The New England Journal of Medicine 2018; 378: 829-39.

21. Bundgaard-Nielsen M, Secher NH, Kehlet H. 'Liberal' vs. 'restrictive' perioperative fluid therapy - a critical assessment of the evidence. Acta Anaesthesiol Scand 2009; 53: 843-51.

22. Brandstrup B, Tonnesen H, Beier-Holgersen R, Hjortso E, Ording H, Lindorff-Larsen K, Rasmussen RS, Lanng C, Wallin L, Iversen LH, Gramkow CS, Okholm M, Blemmer T, Svedsen PE, Rottensten HH, Thage B, Riis J, Jeppesen IS, Teilum D, Christensen AM, Graungoard B, Pott F. Effect of intravenous fluid restriction on postoperative complications: Comparison of to perioperative fluid regimens: A randomized assessor-blinded multicenter trial. Ann Surg 2003; 238: 641-8. 
23. MacKay G, Fearson K, McConnachie A, Serpell MG, Molloy RG, O'Dwyer PJ. Randomized clinical trial of the effect of postoperative intravenous fluid restriction on recovery after elective colorectal surgery. Br J Surg 2006; 93: 1469-74.

24. Holte K, Foss NB, Anderson J, Valentiner L, Lund C, Bie $\mathrm{P}$, Kehlet $\mathrm{H}$. Liberal or restrictive fluid administration in fast-track colonic surgery: a randomized, double-blind study. Br J Anaesth 2007; 99(4): 500-8.

25. Corcoran T, Rhodes JE, Clarke S, Myles PS, Ho KM. Perioperative fluid management strategies in major surgery: a stratified meta-analysis. Anesth Analg 2012; 114(3): 64051.

26. Cecconi M, Parsons AK, Rhodes A. What is a fluid challenge? Curr Opin Crit Care 2011; 17: 290-5.

27. Miller TE, Roche AM, Mythen MMG. Fluid management and goal-directed therapy as an adjunct to Enhanced Recovery After Surgery (ERAS). Canadian Journal of Anaesthesia, Journal Canadien 2015; 62(2):158-68. 